\title{
How can we ever create participation when we are the ones who decide? On natural resource management practice and its readiness for change
}

\section{Lotten Westberg \& Cecilia Waldenström}

To cite this article: Lotten Westberg \& Cecilia Waldenström (2016): How can we ever create participation when we are the ones who decide? On natural resource management practice and its readiness for change, Journal of Environmental Policy \& Planning

To link to this article: http://dx.doi.org/10.1080/1523908X.2016.1264298

曲 Published online: 06 Dec 2016.

Submit your article to this journal $\pi$

Q View related articles ¿

View Crossmark data 


\title{
How can we ever create participation when we are the ones who decide? On natural resource management practice and its readiness for change
}

\author{
Lotten Westberg and Cecilia Waldenström
}

Department of Urban and Rural Development, Swedish University of Agricultural Sciences, Uppsala, Sweden

\begin{abstract}
This article addresses the gap between demands for participatory approaches in natural resource management (NRM) policies and lack of such approaches in the work of environmental authorities. The analysis draws on practice theory, using the case of NRM practice created by Swedish County Administrative Board (CAB) officials. The data originate from officials' reflections during courses designed to strengthen their participatory and collaborative competences. Based on practice theory, officials are seen as participants of a routinised practice in which their interpretations of their work and roles are socially constructed. The analysis shows that the objective of this practice is to protect nature and mitigate resistance from stakeholders through information. These interpretations have acquired a reified nature, making them taken for granted. This stabilises the practice, maintaining the gap between demands in national policies and their implementation. To enable change in the $C A B$ practice, the objective constructed by officials needs to be reinterpreted to produce a rule of law that can be justified and which concurrently permits stakeholder participation. To achieve changes in NRM officials' practice, these need to be seen in their institutional context and comprise the whole system, from international/EU auditing levels to Swedish CABs and the officials' everyday activities.
\end{abstract}

\section{ARTICLE HISTORY}

Received 12 February 2016

Accepted 16 November 2016

\section{KEYWORDS}

Practice theory; policy practice; stability-change; routine; reification

\section{Introduction}

This paper explores an area where policy and practice have long been out of step, namely natural resource management (NRM). For decades, international and national directives and regulations guiding management of the environment and natural resources have called for more collaborative, participatory and democratic approaches (cf. European Commission, 2000; Swedish Government, 2001; UNECE, 1998) but with limited response from the implementing agencies concerned (Buono, Pediaditi, \& Carsjens, 2012; Cooke \& Kothari, 2001; European Commission, 2004; Hovik, Sandström, \& Zachrisson, 2010). Some studies attribute this to the power of structures preventing politically desirable changes, pointing out that bureaucratic organisations such as public environmental agencies are hierarchical and guided by norms ill-suited for working approaches enabling inclusion of multiple interests (Allan \& Curtis, 2005; Lockwood, Davidson, Curtis, Stratford, \& Griffith, 2010; Westberg \& Powell, 2015). Other studies emphasise the power of agency, suggesting lack of appropriate competences among environmental professionals to lead and facilitate processes that involve different, often contradictory, perspectives (Daniels \& Walker, 2001; Margerum \& Whitall, 2004; Westberg, Hallgren, \& Setterwall, 2010; Wiek, Withycombe, \& Redman, 2011). The study presented in this paper sought to overcome this structure-agency divide by employing theories of practice to explore stability and change in implementation of NRM policies.

CONTACT Lotten Westberg lotten.westberg@slu.se E Department of Urban and Rural Development, Swedish University of Agricultural Sciences, PO Box 7012, SE-750 07 Uppsala, Sweden

(c) 2016 Informa UK Limited, trading as Taylor \& Francis Group 
According to practice approaches, the meaning of a practice and its objective, that is, what it should accomplish, are co-created and maintained through the interactions and activities carried out by its participants. New instructions given to a practice are interpreted in relation to this meaning (Gherardi, 1999; Lave \& Wenger, 1991; Yanow, 2003). Practice approaches thus build on the assumption that people do what makes sense to them (Schatzki, 1996), with 'doings' and 'sense makings' taking place simultaneously through continuous interactions that are affected by, and affect, the structures in which a specific practice is embedded. Hence, practice theory permits an understanding that embraces the dialectic relationship between structure and agency (Gherardi \& Perrotta, 2011; Lounsbury, 2008; Miettinen, Samra-Fredericks, \& Yanow, 2009; Nicolini, 2012).

The empirical case described here explored how staff at Swedish County Administrative Boards (CABs) make sense of their work. The CABs are responsible for regional implementation of Swedish environmental policies. These include NRM policies, which are increasingly demanding participatory management approaches. In order to understand the lack of participatory approaches in policy implementation, this study examined how $\mathrm{CAB}$ employees understand their work and how they interpret participatory approaches. Drawing on practice theory, their understanding of work with NRM issues was viewed as an aspect of an NRM policy practice developed at the CABs. Exploring this as a practice helped to understand their ways of responding to the changes in the national policies. To capture this, the study centred on three questions:

- What characterises the meaning and objective of the CAB officials' NRM practice, that is, what is the practice intended to accomplish according to its participants?

- What meanings do the $\mathrm{CAB}$ officials attribute to the participatory approaches demanded by environmental policies and regulations?

- How do $\mathrm{CAB}$ officials maintain the stability of their existing practice by their sense making of policies?

The paper is structured as follows: the next section introduces practice theory and how it is used in the analysis. This is followed by an empirical study based on data from courses offered to CAB officials in order to strengthen their competence for working more inclusively. The paper concludes with a discussion on the difficulties and opportunities for the NRM practice at Swedish CABs as regards including more participatory and collaborative approaches.

\section{Understanding reluctance to change: a practice theory approach}

Practice has increasingly become an organising concept in social studies. Reckwitz (2002) views this as a specific development within cultural studies, contrasting practice theory to other social and cultural theories. A slightly different development is traced by Miettinen et al. (2009), who present practice as central in cultural-historic activity theory, ethnomethodology and pragmatism and in later developments within these theoretical approaches. Theories that centre on practice thus derive from different social and cultural theoretical spheres, but share several common characteristics (Beuger, 2014; Engeström \& Middleton, 1996; Nicolini, 2012; Reckwitz, 2002).

A practice is a routinised pattern of interaction, materially anchored in bodies, artefacts and meaning. Arts, Behagel, Turnhout, de Koning, and van Bommel (2014, p. 4) conclude that practices can be defined as 'an ensemble of doings, sayings and things in a specific field of activity'. A central assumption in practice theory is that meaning is socially constructed and situated (Reckwitz, 2002). Meanings and understandings of what participants in a practice do, and why they do it, are created and manifested in continuous processes of interaction maintained by these participants (Lave \& Wenger, 1991; Nicoloini, Gheradri, \& Yanow, 2003). Participants are considered to act knowledgeably and purposively but, as practices reproduce certain qualities, such as certain ways of knowing how to act, of desiring, using artefacts and understanding the world, participants become carriers of a practice and the practice itself, rather than its participants, is then seen as the unit of analysis (Reckwitz, 2002).

Viewing practice as situated is central in practice theory (cf. Nicolini, 2012). Since what counts as knowledge and competence in a practice is created through the shared understandings of the accomplishments of that 
practice, situated knowledge, as well as situated identities, are produced in the social process (Gherardi, 1999; Lave \& Wenger, 1991). This means that knowledge, skills and identities are developed in relation to the environment in which they occur and to what the practice is meant to achieve in that setting (Lave \& Wenger, 1991; Orlikowski, 2002). Practices are inherently normative, providing guidance on how to act and understand the tasks involved in a particular practice.

To understand how change can come about in practice, agency and structure need to be regarded as interdependently related. This affords a dialectic view on the relationship between actors and the overall structure within which they act that goes beyond approaches of collective action as deterministic (Schatzki, Knorr-Cetina, \& von Savigny, 2001). Structures affect and guide these interactions (Barab \& Kirshner, 2001; Billet, 2007; Nicoloini et al., 2003). However, structures are simultaneously outcomes of, and normatively sustained by, the situated and repeated interactions carried out within a practice. The stability of a practice should not be seen as a static ontological attribute, but as an outcome of the interaction and co-construction of meaning carried out (Nicoloini et al., 2003, p. 27). Yet, as structures, such as orders and routines, emerge in conditions created within a practice, they are always temporary. This temporary nature affords options for change.

\section{Understanding stability and change of practices}

Although theories that use practice as an organising concept permit an understanding of stability and change in organisations and work, practice-based studies often treat workplaces as relatively isolated systems. They tend to focus on changes of practices as potentials for workplace learning and development, without considering the influence of broader institutional structures on the practices under study (Gherardi \& Perrotta, 2011). In contrast, other disciplines, such as marketing, accounting and above all neo-institutional theory, consider organisational and institutional changes as linear processes resulting from exogenous forces, overlooking the interplay between practices and the institutional structures in which they are embedded (Lounsbury \& Crumley, 2007; Reay et al., 2013; Seo, Creed, \& Douglas, 2002). When practices are included in these studies, they are often treated as black-box objects without theoretical motivation (Labatut, Aggeri, \& Girard, 2012; Lounsbury \& Crumley, 2007; Whittington, 2011).

A recent discussion claims that both practice and institutional theories have been inadequate for understanding the role of wider institutional structures and exogenous forces in changes of stable practices and suggests practice-orientated research that takes institutional structures and external forces better into account (Gherardi \& Perrotta, 2011; Miettinen et al., 2009). This has resulted in a number of studies that provide indepth insights into stable workplaces and their response to attempts to transform them through outside interventions (cf. Gherardi \& Perrotta, 2011; Labatut et al., 2012; Swan, Bresnen, Robertson, Newell, \& Dopson, 2010). The overarching conclusion from these studies is that stable workplaces appear to have a life of their own. Whether the external interventions consist of long-term financial support for workplace reforms, organisational restructurings or new legislation, existing practices may exert unexpected resistance. They may adapt to the interventions, but not necessarily in the way intended.

From a practice perspective, these studies indicate that the stability and potential for change in practices need to be analysed in relation to intrinsic processes of meaning and sense making. According to Wenger (1998; see also Ramsten \& Säljö, 2012), the co-creation of meaning is a dual process building on two integrated sub-processes, participation and reification. Participation refers to the general process in which activities and experiences are constantly reinterpreted in the ongoing interaction among the participants in that practice. Reification refers to a process through which the meanings of activities and experiences become fixed and cease to serve as objects for reinterpretation. Such frozen or taken-for-granted meanings (expressed in routines, standard attitudes, certain ways of knowing and understanding the world, etc.) are treated as 'things', in relation to which interpretations of other experiences take place (Wenger, 1998). Reification occurs in all practices and is important, as it structures activities and experiences, provides narratives that help participants orientate themselves and is moreover applied without conscious reflection (Ramsten \& Säljö, 2012). For the same reasons, reification may also be treacherous, for example, by masking supposed clarities or protecting participants from discovering or questioning contradictions inherent in their practice. Participation and reification are 
both important for maintenance of a practice, forming a duality that compensates for each other's limitations (Wenger, 1998).

A change of practice takes place when reified routines change. However, as these routines are created by the participants performing them, not by outside forces, only the participants have opportunities for changing them (Tsoukas \& Chia, 2002). Whether altered external circumstances, for instance new instructions, can affect and effect changes depends on how these external circumstances are perceived and responded to by participants in the practice. Contradictions, inconsistencies, ambiguities and changing external circumstances are integral everyday components of any practice (Guowei, 2011; Tsoukas \& Chia, 2002). They are handled and dealt with in the routines and implicit know-how of participants and may well remain unnoticed. However, some inconsistencies and changing circumstances may be outside the control of the routines of a practice and thus become evident to the participants as disturbances, causing them to question and reflect on the routines that allowed these disturbances to occur. Such responses to changing circumstances make implicit knowing explicit and enable participants to deviate from old patterns, thereby changing their practice (Guowei, 2011; Tsoukas \& Chia, 2002). This understanding of stability and change implies that even if practices are regarded as systems that learn, this learning does not necessarily result in noticeable transformations (Yanow, 2003). Learning might as well imply that participants of a practice manage to resist altered conditions by maintaining stability and keeping up their practice including related identities.

\section{The study: setting, methods and analysis}

These data used in the empirical study originated from an in-service programme aimed at strengthening CAB employees' competence in communication in order to include more of participatory approaches in their work. During the training programme, the $\mathrm{CAB}$ officials had ample opportunities to discuss, reflect on and describe how they envisioned their work and how they perceived the new policy demands. This section summarises how Swedish NRM policies and regulations are implemented and describes the CAB in-service training course. The study design and data analysis methods applied are also described.

\section{The setting: Swedish environmental policy implementation}

The $21 \mathrm{CABs}$ in Sweden are responsible for implementation of NRM policy at the regional level. Although the NRM divisions at the CABs are organised differently, they display important similarities and are required to follow the same general instructions from the Swedish government on controlling conservation and exploitation of natural resources, wildlife and predators (SFS, 2007, p. 825). According to CAB officials, much of their daily work involves communication with stakeholders and the general public, for example, presenting and negotiating plans and decisions related to nature conservation, water and landscape restoration, and game and predator management.

In recent decades, efforts by the Swedish government to improve nature conservation and to protect certain predators have been strongly questioned, particularly by people in rural areas. The government has partly dealt with this by introducing policies aimed at encouraging environmental authorities to increase inclusion and participation by local communities and stakeholder groups. This approach is intended to increase the legitimacy of, and mitigate opposition to, policy measures for strengthening nature conservation and predator protection (cf. SEPA \& SFA, 2005; Swedish Government, 2001; Swedish National Heritage Board, 2008).

In order to encourage a more participatory approach in the work of Swedish environmental authorities, in 2007, the government commissioned the Swedish Environmental Protection Agency (SEPA) to develop a programme for improving the communication skills of the CAB officials concerned. The overall objective of this programme, called Dialogue for Nature Conservation (term 2008-2011), was to provide NRM officials within the fields of conservation, outdoor recreation and wildlife management at CABs with communication tools for facilitating dialogue, creating democratic processes and acquiring a basic understanding of conflict prevention and conflict management (SEPA, 2008). The programme was part of the ordinary in-service training at the 
CABs and included five different courses. A basic course was given several times per year and four advanced courses were given once a year. Approximately 500 officials attended one or several of the courses.

The programme can be seen as an intervention in the NRM practice of CAB officials based on the assumption that better communication skills among staff would help implement the new policies, an approach trusting the 'competent agent'. However, top-down, expert-driven ways of working that exclude influence by concerned stakeholder groups still seem to prevail at the CABs (Hallgren \& Westberg, 2015; Hovik et al., 2010; Sandström, 2008; Westberg \& Powell, 2015). It is in order to be able to understand why this is the case that practice approaches are drawn on in the present study.

\section{Method}

The study builds on data from the basic course in the programme, given 4-5 times per year between 2008 and 2010. The aim of the analysis was not to evaluate the impact of the course on policy practice at the CABs, but to use the course participants' descriptions, experiences and reflections during the course as data in order to understand their practice and its readiness for change. A brief description of the overall structure and content of the basic course is given below (for more information, see SEPA, 2008; Westberg et al., 2010).

The basic course aimed to provide the officials with the theoretical understanding and communication skills needed to negotiate multiple perspectives and interests, manage issues relating to trust, increase public involvement in proposed measures and critically analyse participatory processes. The course consisted of two separate sessions, comprising 2 and $1 \frac{1}{2}$ days of training, respectively. During the first session, the participants were introduced to:

(i) A model in which communication was presented as a mutual process where those involved construct a shared meaning of the phenomena at hand. This was contrasted with an understanding of communication as a transfer of neutral, decontextualised pieces of information from sender to receiver.

(ii) A model of democracy and participation grounded in Habermas' (1989) view of the public sphere and Dahl's (1991) five criteria of democratic processes. This was used as a basis for discussions about the desirability and feasibility of stakeholder participation in different NRM projects.

(iii) A conflict management model based on Glasl (1999) to discuss and distinguish between 'clashes of interest' with potential for learning and 'conflicts' with mistrust in continued communication.

Applying these conceptual models to work at the CABs formed the basis for discussions and exercises in the course. The participants created, for example, short role-plays based on their experiences of meeting target groups (such as landowners, hunters, cattle farmers, municipalities, local communities, road construction companies and wind power companies) in complicated, tense or even threatening situations. These role-plays provided opportunities, based on the conceptual models, for practically testing ways of affirming, instead of stifling, criticism and resistance from target groups in situations resembling the participants' real-life experiences. To give the participants additional opportunities for concrete practice in insights gained during the first session, they were encouraged to carry out a home assignment before the second session. The assignments relevant to this study were:

- To observe an ordinary everyday communication activity led by a colleague, addressing stakeholders or target groups as part of the routine work of the CAB.

- To design and implement an activity addressing stakeholders or target groups based on the conceptual model(s).

Both assignments included presenting a written report describing, evaluating and critically reflecting upon the activity in relation to one or several of the conceptual models provided by the course.

When the participants returned for the second session, which took place about a month after the first, around half had written some kind of assignment. This session was organised in group and plenary discussions 
on the assignment reports and on the participants' experiences of having explored, challenged and evaluated everyday activities in relation to participatory approaches. The discussions also included the wider implications of their insights from these experiences on their everyday work. The course setting thus afforded ample opportunities for the participants to reflect on their work together with other participants, that is, colleagues in the same NRM practices at a CAB.

\section{Data collection and analysis}

As one of several trainers within the programme, one of the authors had access to course participants' reflections on their practice during the courses, as well as their oral and written reflections on experiences of having critically explored and tested the opportunities for more inclusive and participatory communication styles in real-life settings. The data thus include information about NRM officials' doings as they describe them, their reasoning about consequences of these doings and their way of making sense of participatory approaches suggested by environmental policies and regulations. These are critical aspects of how participants perceive their work as a practice proposed by Schatzki (1996) for understanding a practice.

Material from 14 basic courses involving $325 \mathrm{CAB}$ officials active in NRM policy implementation was used in the analysis. This material comprised two categories. The first was written notes taken by course leaders during the first and second sessions when participants: (i) presented themselves and their expectations for the course; (ii) presented the results of small group discussions on their experiences of difficult communication situations; (iii) discussed their experiences of trying to handle complicated meetings with stakeholders or target groups more inclusively in connection with the short role-plays; (iv) reflected upon what they had gained from the course by the end of the first session; (v) discussed and reflected upon experiences of practically testing the conceptual models in home assignments; (vi) evaluated and reflected, at the end of the second session, on the implications of what they had learnt during the course in relation to their practice.

The second category of data included 48 written assignments produced by the course participants. In total, the 325 participants produced 127 assignments, but most were only very brief notes about the chosen task and how it was performed. The 48 assignments selected for analysis were chosen, as they included sufficient information about why the participant chose the task, the results and how they interpreted them. Together, the empirical material provided sufficient rich and varied information for in-depth analysis of how CAB officials make sense of and reflect over their work, its motives and aims, providing a basis for the analysis of it as a practice.

The material was analysed as recommended by Crang and Cook (2007). After repeated readings of the data for familiarisation purposes, it was coded into three thematic categories: (1) descriptions and reflections about current work, for example, what officials did and why they did it, what they took for granted or found important and why; (2) their professional role, for example, the skills they needed to do what they did and why; and (3) their responses to ideas and experiences of having tested the models for more participatory and democratic approaches at work, for example, what they found valuable, challenging or irrelevant in relation to their practice and why. In the next step, these themes were interpreted to identify recurring meanings in descriptions of participants' work and meanings given to their new experiences of trying to work more inclusively and participatory. Based on the assumptions described above on how a practice maintains stability and what is required for change, the potential for the CAB NRM practice to change towards including participatory policies was then identified.

\section{Analysis and results}

The analysis provided evidence of such strong coherence in the CAB officials' understandings and reflections on their work that it was possible to identify a shared CAB NRM practice. Depending on the area of expertise, the specific activities included in the everyday work of individual NRM officials varied, but they shared overall experiences and working conditions. They also had a similar natural science background, mainly in biology. The similarities in officials' working conditions and perspectives were obvious when they described their 
work, problems, missions and roles. In fact, a recurring reason officials gave for why they appreciated the course was that their approaches and concerns were shared and recognised by their course-mates, regardless of which $\mathrm{CAB}$ or subject area they represented. They took part in discussions and suggested solutions to each other's problems in a way that, according to Lave and Wenger (1991), participants who share the same practice are likely to do, as they know the same things and share the understanding of why it is important to know them (see also Arts et al., 2014).

\section{The objective and meanings of NRM practice}

As state agencies, the Swedish CABs have the mission to protect valuable nature. However, for the purposes of this analysis, it was not the wording of the task that was important, but how CAB officials made sense of it. It is the interpretations of the missions of a practice that guide its participants in their organisation and distribution of everyday tasks, in their priorities, framing of problems and search for solutions (Lave \& Wenger, 1991; Schatzki, 1996). The analysis made it possible to identify some fundamental characteristics of the officials' understandings of their work, its meanings and objectives, and their roles as participants of the practice.

In the first session, the officials were asked to present themselves and describe their expectations for the course. The quotes below illustrate why they saw a need to become more skilled communicators:

I don't have any specific expectations, though it is important to get some tips on how to communicate about, and create support for, nature conservation.

It's always difficult to make landowners take a pride in their estates.

I am here to learn about how to make people understand that there are good things with nature, so we can avoid conflicts.

By becoming skilled at communicating in a convincing way, the officials hoped to evoke commitment and gain support for their task of protecting nature. The home assignments revealed similar interpretations:

In the ideal world they themselves [landowners] are supposed to understand that they should do something to protect the small jewels that they possess, and thus feel more involved in the process.

The quotes above illustrate a recurring theme in the data: it would facilitate the work of the CAB officials if their target groups shared their view on nature and its 'jewels', but such an understanding was generally lacking and therefore they felt they needed the skills to convince their target groups to accept CAB decisions and measures:

The CAB's intention with arranging the meeting was to reconnect with the landowners and make them accept the idea of establishing a nature reserve.

Generally, the reason given for the perceived obstacles, such as resistance to CAB measures, was that the officials had failed to inform stakeholders in an accurate and convincing way. Accordingly, the suggested solution was to improve the information. For example, as her assignment, one official evaluated a meeting between the $\mathrm{CAB}$ and City Office representatives regarding restoration of streams. Several of the representatives objected to the $\mathrm{CAB}$ ideas which resulted in: ' ... some mess'. The solution suggested by the official was more carefully planned information:

... in upcoming workshops, more information will be sent out in advance. In this way, the participants can prepare and decide what questions they want to focus on.

Throughout the data, statements indicated that stakeholders were welcome to feel involved in management, provided that they understood and appreciated nature in the same way as the officials and resistance to measures taken by the CABs was attributed to lack of knowledge and understanding. This suggests that the NRM practice is grounded in the idea that its participants, unlike target groups, understand the 'right' things about nature in the 'right' way, and that their role is to make the stakeholders understand this.

Taking into account that the officials work on behalf of the Swedish government and that their authority has legal support, one could imagine that they could easily make decisions that contravened stakeholders' interests. 
However, the analysis showed that authority was preferably exercised through convincing information and knowledge transfer. This was why they took the course. The alternative, to force through decisions, risked prompting more active resistance ('.. so that we can avoid conflicts'). However, both alternatives departed from the same meaning of NRM practice; that the officials are indisputably right in their aim of protecting nature in a way that makes sense within their practice, while target groups must be made to accept.

The NRM practice gains legitimacy to express authority from the understanding among its participants that what they regard as right is based on objective facts. Activities included in the everyday work of the officials, such as identifying and assessing areas of importance for nature conservation, making trade-offs to map out the precise boundaries of planned nature reserves and approving or rejecting applications for culling carnivores or exploitation of natural resources, were regarded as neutral and emotion-free. This assumption seemed in fact to be one of the pillars maintaining the overall meaning of the practice. In course exercises and discussions, officials were seldom explicit regarding this assumption, but it was implicit in arguments used to dismiss protests and challenges by those affected by CAB measures. Such protests were not based on facts, according to officials, but on special interests and stakeholders' emotions. In fact, stakeholders were described as ' ... totally absorbed by their emotional perspective' when questioning decisions and actions taken by the officials. During one of the courses, one official even cried out:

How can we deal with the contrasts between facts and emotions? Good pasture land can be perceived as poor by a farmer!

'Good pasture land' refers to the biologically diverse, but low-yielding, pastures created by traditional animal husbandry, which from a modern agricultural point of view are of low value. Thus, both positions can be seen as representing facts and emotions. However, the idea of neutrality that gives legitimacy and authority to their practice is too crucial for maintaining its stability to allow such a conclusion to be recognised by the $\mathrm{CAB}$ official.

To summarise, the following characteristics of the objective and meanings of the NRM practice were identified:

- The objective of the practice is to make the 'right' decisions regarding NRM and to concurrently mitigate resistance from stakeholders through information.

- The role of the officials builds on an identity as experts who, in contrast to their target groups, know how to value and protect nature in the 'right' way.

- This expertise is based on neutral facts, while their target groups' knowledge and values are under the influence of emotions and personal interests.

- Resistance to measures taken by the CAB NRM practice is regarded as a communication problem that can be solved by better planned, more appropriate information.

Oral and written statements supporting these characteristics recurred throughout the empirical material. Implicitly or explicitly, they served as starting points for descriptions and reflections on the officials' work and experiences. Thus, it is reasonable to assume that they are essential for the meanings that keep the CAB NRM practice together and maintain its stability. Moreover, statements reflecting these characteristics were never questioned. Thus, the ideas that give legitimacy to the expertise and authority of practice seem reified, implying that they are not readily open to reinterpretation but rather serve as fixed points around which interpretations of activities and experiences centre. The next section explores how these reified meanings fitted within the officials' experiences of testing tools for more inclusive communication provided by the course.

\section{The meaning of participatory approaches}

Course participants never referred to the new policies on participatory environmental management as their motive for attending the course. As mentioned, the reason generally given was a wish to improve their skills in transferring knowledge and convincing target groups to accept assumptions on NRM that were meaningful from their own perspectives. The changes in policies seemed to be of no concern and were not regarded by CAB 
staff as tasks that concerned them. Instead, it was the course, with its objectives and training, that inspired them to test new and more inclusive ways of communicating and arranging activities. Their responses to the course content and tasks and their reflections on experiences during the assignments showed what participation meant for the officials, and how it fitted their understanding of what their practice should accomplish and why. Their responses also revealed what participatory work cannot mean in relation to their practice and why.

One official described a situation where, inspired by the course, she arranged a face-to-face meeting with a landowner in an area destined to become a nature reserve, instead of making the normal time-saving phone call. This was in order to 'increase the landowner's sense of ownership' of the management plan for the reserve. According to the official, the meeting proved constructive because the landowner perceived the personal meeting as 'a generous gesture' from the official. Moreover, the official was surprised that the landowner had great knowledge about the area that contributed substantially to the management plan:

... we exchanged ideas about the area and how to manage it, which could lead to opportunities to protect the biological values of the area even better in future.

This official's experiences of meeting and discussing a management plan with a landowner made sense in relation to the objective of the NRM practice. Other officials who were lucky to gain similar kinds of responses from their target groups, when testing more inclusive ways of communicating, reacted similarly. Unsurprisingly, stakeholder participation was appreciated when the stakeholders seemed to accept and support reified meanings concerning who had the authority to define valuable nature and decide how these values should be managed.

Officials who met resistance and protests in efforts to include interest groups in management were less enthusiastic. One home assignment described a situation where a landowner requested permission to cut trees in his forest, located beside and partly within the boundaries of a nature reserve. The official met the landowner to communicate the regulations that apply to forestry in the area: 'At the beginning of the meeting the landowner was positive and said he is interested in nature conservation himself, the official wrote, continuing:

However, when he understood that he would not get a permit to cut down the trees he wanted, he became less compliant ... he said that he felt brushed aside. My reflection here is that this is the very problem with participation and dialogue. As officials at the $\mathrm{CAB}$ dealing with maintenance of nature reserves, we have little or no opportunity to conduct a dialogue with landowners regarding whether to protect a certain area or not.[...] What we can do is to focus on discussing the geographical borders of the reserve and ensure that the communication runs smoothly during the process.

The quote above illustrates both what can and what cannot be meant by stakeholder participation in relation to the objective of NRM practice. Participation cannot mean that officials allow stakeholders, with their emotions and subjective knowledge, to influence the definitions and scope of NRM. Only communication and information about decisions, definitions and scope made by the practice can be improved. The reasons behind these limitations were summed up by one official in this clarifying way:

How can we ever create participation when we are the ones who decide?

The officials' reasoning in the home assignments and their discussions about their experiences of testing new more inclusive communication can be seen as negotiations of the meaning of participation in relation to the objective of their practice (cf. Wenger, 1998). In these negotiations, the CAB officials generally arrived at a meaning of participation that involved making the frames for possible influence by target groups clear and transparent to them and by creating more opportunities for target groups to understand decisions and measures taken by the $\mathrm{CAB}$. The officials recognised that such approaches could reduce resistance among their target groups and therefore speed up CAB tasks, making their work run more smoothly in the long run. The only downside they saw was that such approaches would be more time consuming in the start-up phase. To implement what they saw as possible participatory approaches on a more regular basis, the CAB officials claimed that they would need general working instructions from senior management supporting them and recognition of what participation would imply. Such institutional changes would be needed to help them change their routines towards the limited version of participation they regarded as possible. These negotiations over 
what participation implies suggest that reified aspects of the objective of NRM practice also guide what can be considered participatory working approaches. Approaches that challenged these limiting aspects were dismissed, as they would derail the meaning and objective of NRM practice.

\section{The situated meaning of participation}

An important general assumption inherent in practice theory is that relevant knowledge and skills in a given practice are situated and related to the meaning of the objective of the particular practice (Lave \& Wenger, 1991; Nicoloini et al., 2003). This assumption agrees well with the results of this study. When the officials stepped out of the NRM practice and their role as experts in relation to stakeholders and into other practices and situations where they had other roles, other interpretations of participation and other skills became salient.

One aim with the basic course was to encourage CAB officials to develop critical perspectives on their current working routines. The models on democracy and participation presented were intended to serve as tools in development of such perspectives. In home assignments, course participants were instructed to apply the models to evaluate communication situations taking place in their everyday work. These evaluations were generally quite superficial, however, and participants seemed to have difficulty seeing that the communication situations they analysed and which their colleagues managed could be designed or conducted in anything other than the routine way. In other words, they appeared quite incapable of applying the models as evaluation tools in the intended way. The home assignments typically included a brief description of the purpose of the activity, what happened and ended with some rather anecdotal conclusion stating that despite the fact that: '... the meeting was open and democratic' and: ' ... enabled the audience to come up with criticism and opinions' none, or very few in the audience had asked for the floor.

It is, of course, possible that the instructions and conceptual models the officials were given to use were inappropriate as tools for analysis and evaluation of $\mathrm{CAB}$ communication activities, or that the officials simply lacked the appropriate training in using them. However, some home assignments focusing on internal $\mathrm{CAB}$ meetings, and not on meetings with stakeholders, revealed that this was not the case. In these internal meetings, the course participants proved very able to use the conceptual models to scrutinise and problematise the meeting design in relation to participation and democracy. In these meetings, they were the target group for information and imposed ideas, and subject to decisions from senior managers. They critically identified and discussed crucial weak points in meetings where they had no opportunity to influence the content or agenda or even express their opinion. They now possessed the skills to realise that in some cases, they were invited to meetings under the false pretence of participating in decision-making, but were given no space for joint decision-making or even the opportunity to understand the decision-making process.

One official described an internal change process introduced at her CAB unit with the overall stated aim of creating a 'basis for shared values and visions to guide the future work of the CAB'. She concluded that, despite these inclusive ambitions, the process was:

... forced upon the staff by $\mathrm{CAB}$ management, aiming to make the staff understand how beneficial the suggested changes would be for dealing with future challenges

and that the participatory approach 'was of a cosmetic nature' and 'was a meaningless exhibition of pseudodemocracy'.

The insights and conclusions revealed by these quotes never emerged in the participants' analysis of CAB meetings with NRM stakeholders outside the $\mathrm{CAB}$, despite the fact that, based on the descriptions given, many of these meetings were similar in nature to the most criticised internal CAB meetings. When observing and analysing meetings with NRM stakeholders, the officials were instead preoccupied by whether they managed to get their message across and gain acceptance from their audience. This reveals the situatedness in the course participants' competence and understanding of participation, and that the meaning of participation was linked to the specific NRM practice within which meetings with stakeholders were performed, and which they can be seen as carriers of. Outside that practice and in other situations, other skills and competences became available to the $\mathrm{CAB}$ staff. 
Thus, the ability of the CAB officials to critically evaluate their work with stakeholder participation was limited when it did not coincide with the object of the NRM practice, or the professional roles they identified with. They did not have the ability to generalise from the authoritarian approach they criticised in internal CAB meetings to their own everyday work with stakeholders. Again, this can be seen as an example of reification and a consequent lack of ability by officials to reflect on inconsistencies between how they wanted to be treated by their managers and how they treat stakeholders. Such processes contribute to the stability of a practice and reluctance to change. It would appear from some home assignments that CAB senior managers handle their staff in the same way as the staff handle their stakeholders, something which probably contributes to the stability of the practice. The hope for change lies in the CAB officials' capacity to understand participation when they reflect over their position in their own organisation.

\section{Conclusions}

Using practice theory, this study examined the gap between demands for participatory approaches in Swedish national NRM polices and lack of such participatory approaches in practice. According to practice theory, the NRM officials are participants of a routinised practice in which their interpretations of the objective of their work and of their professional roles are socially constructed in ongoing processes of interpretation and interaction. These routinised ways of acting are stabilised by the parallel processes of participation and reification. In interpretations of meanings and roles, through reification, certain aspects of a practice become so taken for granted that they are no longer available for reflection and reinterpretation. Problems and inconsistencies caused by such reified aspects of practices may not even be perceived until they become so obvious that participants of the practice are forced to attend to them. However, what attention to inconsistencies leads to is uncertain. There are strong tendencies to maintain practices. It is because practice theories afford these kinds of analysis of stability and change in activities that we draw on them in this paper.

The results showed that Swedish CAB officials responsible for first-line implementation of Swedish NRM polices share the view that the objective of their work is to make the right decisions regarding NRM and concurrently mitigate resistance from stakeholders through information. They see themselves as experts who know how to value and protect nature correctly, through expertise based on neutral facts. In contrast, they view the knowledge and values of the stakeholders they encounter as being under the influence of emotions and personal interests. Resistance to NRM measures is regarded as a communication problem that can be solved by better planned, more appropriate information. Collaborative and participatory approaches to NRM policy implementation are viewed as feasible only in very limited ways. Participation was seen as a means for making the frames for possible influence from the target groups clear to them and for encouraging stakeholders to understand and accept the decisions taken by the authorities. Moreover, the officials claimed that to use even such limited approaches on a more regular basis, they would need support from senior management.

The analysis suggests that the officials' understandings of the object of the practice, their roles as experts and their interpretations of participation are more or less reified aspects of a shared NRM practice. Approaches that challenged these interpretations were either dismissed or not even distinguished as part of the practice, despite national policies and in-service training encouraging participatory approaches in their work. Such changes would derail the meaning and objective of their NRM practice. These reified interpretations thus stabilised their practice, making it difficult to change NRM policy implantation and maintaining the gap between demands in national policies and their implementation.

The opportunities for change identified here were on two levels. First, in situations outside NRM practice, the officials were able to distinguish whether processes were participatory or not. This came up in their stories about how they themselves were subject to managerial interventions far from participatory. Thus, it was not their capacity to understand participation that was lacking, but their capacity to relate it to their NRM practice. Their competence to distinguish and critically evaluate participatory practices in other situations than their NRM practice indicates scope for change. Second, their observation that simply spending more time on communication with stakeholders about frames for decisions would require approval from their own managers indicates that they themselves are part of a hierarchical organisation that does not promote collaborative 
approaches as models for acting. The hierarchical context can also be traced in the self-perceived objectivity that characterised the officials' interpretations of their expertise. Such interpretations have been observed previously among decision-makers (Uhlman \& Cohen, 2007) and public bureaucracies in general (Casey, 2004), and have been regarded as supported by the hierarchical structures characterising the organisations involved. This is reflected in Boschken's (1982, p. 31) statement that: 'Bureaucracy in itself contains the assumption of neutrality and objectivity of the administration and administrative staff. According to Leskinen (1997), these assumptions may also be reinforced within bureaucracies where, as in Swedish CABs, the professionals are trained in natural sciences with its positivist epistemology.

Thus, in order to achieve changes in NRM officials' practices, these need to be seen in their institutional context. The in-service training focused on the officials' understanding, based on the assumption that their competence in communication and managing collaborative methods was the limiting factor for up-take of collaborative approaches. The analysis showed that this was not the case and that reified interpretations of their work actually hindered adaptation to the new NRM policies. However, making these reified understandings available for reinterpretation probably requires processes involving not only the officials at the first line of NRM policy implementation. The objective of their practice needs to be reinterpreted to a balancing of a rule of law, which can be justified and nationally legitimate, with collaborative approaches that allow local stakeholders' participation. This would need to permit local variations in policy implementation and a development of competence to deliberate when and how such variations are relevant and justifiable. Without such an understanding of NRM policy implementation characterising the whole system, from international/EU auditing levels through to CABs in Sweden, it will be difficult to achieve greater implementation of participatory practices than is the case today. However, such changes may well increase the local trust in authorities.

\section{Disclosure statement}

No potential conflict of interest was reported by the authors.

\section{Notes on contributors}

Dr Lotten Westberg is a researcher at the division of Environmental Communication at the Department of Urban and Rural Development at the Swedish University of Agricultural Sciences specialising in research on dialogue, collaboration, learning and related ideas inherent in modern policies on natural resource governance. She had published within interdisciplinary environmental research journals in particular, where she develops empirical work from a practice theoretical perspective.

Dr Cecilia Waldenström is a senior lecturer in rural development at the Department of Urban and Rural Development at the Swedish University of Agricultural Sciences, specialising in rural policies, agrarian change and learning processes connected to these issues. Her broader research interests include the role of voluntary work and civil society in EU rural policy projects as well as learning in the context of local rural development and in connection to EU rural policy programmes.

\section{References}

Allan, C., \& Curtis, A. (2005). Nipped in the bud: Why regional scale adaptive management is not blooming. Environmental Management, 36(3), 414-425.

Arts, B., Behagel, J., Turnhout, E., de Koning, J., \& van Bommel, S. (2014). A practice based approach to forest governance. Forest Policy and Economics, 49, 4-11.

Barab, S., \& Kirshner, D. (2001). Guest editors' introduction: Rethinking methodology in the learning sciences. Journal of the Learning Science, 10(1\&2), 5-15.

Beuger, C. (2014). Pathways to practice: Praxiography and international politics. European Political Science Review, 6(3), $383-406$. Billet, S. (2007). Including the missing subject: Placing the personal within the community. In J. Hughes, N. Jewson, \& L. Unwin (Eds.), Communities of practice. Critical perspectives (pp. 55-67). New York, NY: Routledge.

Boschken, H. L. (1982). Land use conflicts. Organizational design and resource management. Urbana: University of Illinois Press.

Buono, F., Pediaditi, K., \& Carsjens, G. (2012). Local community participation in Italian national parks management: Theory versus practice. Journal of Environmental Policy \& Planning, 14(2), 189-208.

Casey, C. (2004). Bureaucracy re-enchanted? Spirit, experts and authority in organizations. Organization, 11, 59-79.

Cooke, B., \& Kothari, U. (Eds). (2001). Participation the new tyranny? London: Zed Books. 
Crang, M., \& Cook, I. (2007). Doing ethnographies. London: Sage.

Dahl, R. A. (1991). Democracy and its critics. London: Yale University Press.

Daniels, S., \& Walker, G. (2001). Working through environmental conflicts. The collaborative learning approach. Westport, CT: Praeger.

Engeström, Y., \& Middleton, D. (1996). Introduction: Studying work as a mindful practice. In Y. Engeström \& D. Middleton (Eds.), Cognition and communication at work (pp. 1-14). New York, NY: Cambridge University Press.

European Commission. (2000). Directive 2000/60/EC of the European parliament and of the council of 23 October 2000 establishing a framework for community action in the field of water policy. Official Journal 22 December 2000 L 327/1. Brussels: European Commission.

European Commission. (2004). Life focus/life-nature: Communicating with stakeholders and the general public. Luxembourg: Office for Official Publications of the European Commission. Retrieved from http://ec.europa.eu/environment/life/publications/ lifepublications/lifefocus/documents/natcommunicat_lr.pdf

Gherardi, S. (1999). Learning as problem-driven or learning in the face of mystery? Organization Studies, 20(1), 101-123.

Gherardi, S., \& Perrotta, M. (2011). Egg dates sperm: A tale of practice change and its stabilization. Organization, 18, 595-614.

Glasl, F. (1999). Confronting conflict. A first-aid kit for handling conflicts. London: Hawthorn Press.

Guowei, J. (2011). Articulating circumstance, identity and practice: Toward a discursive framework of organizational changing. Organization, 18, 45-64.

Habermas, J. (1989). The structural transformation of the public sphere: An inquiry into a category of bourgeois society. Cambridge: Polity.

Hallgren, L., \& Westberg, L. (2015). Adaptive management? Observations on the role of understanding-orientated communication practice in wildlife management. Wild Life Biology, 21(3), 165-174.

Hovik, S., Sandström, C., \& Zachrisson, A. (2010). Management of protected areas in Norway and Sweden: Challenges combining central governance and local participation. Journal of Environmental Policy and Planning, 12(2), $159-177$.

Labatut, J., Aggeri, F., \& Girard, N. (2012). Discipline and change: How technologies and organizational routines interact in new practice creation. Organization Studies, 33(1), 39-69.

Lave, J., \& Wenger, E. (1991). Situated learning: Legitimate peripheral participation. New York, NY: Cambridge University Press.

Leskinen, A. (1997). Environmental planning as learning. The principle of negotiation, the disaggregative decision-making method and parallel organisation in developing the road administration. Department of Economics and Management. Publication 5. Helsinki: University of Helsinki.

Lockwood, M., Davidson, J., Curtis, A., Stratford, E., \& Griffith, R. (2010). Governance principles for natural resource management. Society and Natural Resources, 23, 986-1001.

Lounsbury, M. (2008). Institutional rationality and practice variation: New directions in the institutional analysis of practice. Accounting Organizations and Society, 33, 349-361.

Lounsbury, M., \& Crumley, E. (2007). New practice creation: An institutional perspective on innovation. Organization Studies, 28 (7), 993-1012.

Margerum, R. D., \& Whitall, D. (2004). The challenges and implications of collaborative management on a river basin scale. Environmental Planning and Management, 47, 409-429.

Miettinen, R., Samra-Fredericks, D., \& Yanow, D. (2009). Re-turn to practice: An introductory essay. Organization Studies, 30(12), 1309-1327.

Nicolini, D. (2012). Practice theory, work \& organization. An introduction. Oxford: Oxford University Press.

Nicoloini, D., Gheradri, S., \& Yanow, D. (Eds.). (2003). Introduction: Toward a practice-based view of knowing and learning in organizations. In D. Nicoloini, S. Gheradri, \& D. Yanow (Eds.), Knowing in organizations, a practice-based approach (pp. 3-31). New York, NY: M-E Sharpe.

Orlikowski, W. J. (2002). Knowing in practice: Enacting collective capability in distributed organizing. Organization Science, 13(3), 249-273.

Ramsten, A.-C., \& Säljö, R. (2012). Communities, boundary practices and incentives for knowledge sharing? A study of the deployment of digital control systems in a process industry as a learning activity. Learning, Culture and Social Interaction, 1, 33-44.

Reay, T., Chreim, S., Golden-Biddle, K., Goodrick, E., Williams, B. E., Casebeer, A., ... Hinings, C. R. (2013). Transforming new ideas into practice: An activity based perspective on the institutionalization of practices. Journal of Management Studies, 50, 963-990.

Reckwitz, A. (2002). Toward a theory of social practices. A development in culturalist theorizing. European Journal of Social Theory, 5(2), 243-263.

Sandström, E. (2008) Reinventing the commons: Exploring the emergence of local natural resource management arrangements. Department of Urban and Rural Studies. Publication 2008:48. Uppsala: Swedish University of Agricultural Sciences.

Schatzki, T. (1996). Social practices. A wittgensteinian approach to human activity and the social. New York, NY: Cambridge University Press.

Schatzki, T., Knorr-Cetina, K., \& von Savigny, E. (Eds.). (2001). The practice turn in contemporary theory. New York, NY: Routledge. 
Seo, M.-G., Creed, W., \& Douglas, W. E. (2002). Institutional contradictions, praxis, and institutional change: A dialectical perspective. The Academy of Management Review, 27(2), 222-247.

SEPA. (2008). Dialogue for nature conservation. Skills development in dialogue, local participation and conflict management within nature conservation and the management of natural resources (Report 5847). Retrieved from http://www.naturvardsverket.se/ Om-Naturvardsverket/Publikationer/ISBN/5800/978-91-620-5847-0/

SEPA \& SFA. (2005). Nationella Strategier för formellt skydd av skog [Swedish EPA \& Swedish Forest Agency: National strategies for formal forest protection]. Retrieved from https://www.naturvardsverket.se/Documents/publikationer/620-1243-6.pdf

SFS. (2007). Swedish code of statues, 285. Retrieved from http://www.lansstyrelsen.se/kronoberg/En/om-lansstyrelsen/vartuppdrag/Pages/default.aspx

Swan, J., Bresnen, M., Robertson, M., Newell, S., \& Dopson, S. (2010). When policy meets practice: Colliding logics and the challenges of mode 2 initiatives in the translation of academic knowledge. Organization Studies, 31(09\&10), 1311-1340.

Swedish Government. (2001). En samlad naturvårdspolitik [A shared nature conservation policy]. Swedish Government document 2001/02:173. Stockholm: Fritzes.

Swedish National Heritage Board. (2008). Förslag till genomförande av den europeiska landskapskonventionen $i$ Sverige. Slutredovisning av regeringsuppdrag [Proposal for implementation of the European landscape convention in Sweden. The final report of the government commission] Rapport 103-03188-2006 (2008-01-15). Retrieved from http://www.raa.se/ publicerat/rapp2008_1.pdf

Tsoukas, H., \& Chia, R. (2002). On organizational becoming: Rethinking organizational change. Organization Science, 13(5), 567-582.

Uhlman, E., \& Cohen, G. (2007). 'I think it, therefore it is true': Effects of self-perceived objectivity on hiring discrimination. Organizational Behaviour and Human Decision Processes, 104, 207-223.

UNECE. (1998). Convention on access to information, public participation in decision-making and access to justice in environmental matters. Retrieved from http://ec.europa.eu/environment/aarhus/

Wenger, E. (1998). Communities of practice. Learning, meaning and identity. New York, NY: Cambridge University Press.

Westberg, L., Hallgren, L., \& Setterwall, A. (2010). Communicative skills development of administrators: A necessary step for implementing participatory policies in natural resource management. Environmental Communication, 4(2), 225-236.

Westberg, L., \& Powell, S. (2015). Participate for women's sake? - A gender analysis of a Swedish collaborative environmental management project. Society and Natural Resources. doi:10.1080/08941920.2015.1014594

Whittington, R. (2011). The practice turn in organization research: Towards a disciplined transdisciplinarity. Accounting, Organization and Society, 36, 183-186.

Wiek, A., Withycombe, L., \& Redman, C. (2011). Key competencies in sustainability: A reference framework for academic program development. Sustainability Science, 6, 203-218.

Yanow, D. (2003). Seeing organizational learning: A 'cultural' view. In D. Nicoloini, S. Gheradri, \& D. Yanow (Eds.), Knowing in organizations, a practice-based approach (pp. 32-52). New York, NY: M-E Sharpe. 